This document is the accepted manuscript version of the following article:

Penone, C., Allan, E., Soliveres, S., Felipe-Lucia, M. R., Gossner, M. M., Seibold, S., ... Fischer, M. (2019). Specialisation and diversity of multiple trophic groups are promoted by different forest features. Ecology Letters, 22(1), 170-180.

https://doi.org/10.1111/e1e.13182

\title{
Specialisation and diversity of multiple trophic groups are promoted by different forest
}

\section{features}

\section{Authors list:}

Caterina Penone ${ }^{1}$, Eric Allan ${ }^{1}$, Santiago Soliveres ${ }^{2}$, María R Felipe-Lucia ${ }^{1}$, Martin M Gossner ${ }^{3}$, Sebastian Seibold ${ }^{4}$, Nadja K Simons ${ }^{4}$, Peter Schall ${ }^{5}$, Fons van der Plas ${ }^{6}$, Peter Manning ${ }^{7}$, Rubén D Manzanedo $^{8,9}$, Steffen Boch ${ }^{1,10}$, Daniel Prati ${ }^{1}$, Christian Ammer $^{5}$, Jürgen Bauhus ${ }^{11}$, François Buscot ${ }^{12,}$ ${ }^{13}$, Martin Ehbrecht ${ }^{5}$, Kezia Goldmann ${ }^{12}$, Kirsten Jung ${ }^{14}$, Jörg Müller ${ }^{15}$ 16, Jörg C Müller ${ }^{17,}{ }^{18}$, Rodica Pena $^{19}$, Andrea Polle ${ }^{19}$, Swen C Renner ${ }^{20}$, Liliane Ruess $^{21}$, Ingo Schönig ${ }^{22}$, Marion Schrumpf ${ }^{22}$, Emily F Solly $^{22,23}$, Marco Tschapka ${ }^{14,24}$, Wolfgang W Weisser ${ }^{4}$, Tesfaye Wubet ${ }^{12,13}$, Markus Fischer ${ }^{1,7}$

\section{Affiliations}

1. Institute of Plant Sciences, University of Bern, Switzerland

2. Department of Ecology, University of Alicante, Alicante, Spain

3. Forest Entomology, Swiss Federal Research Institute WSL, Birmensdorf, Switzerland

4. Chair for Terrestrial Ecology, Department of Ecology and Ecosystem management, Technische Universität München, Freising, Germany

5. Silviculture and Forest Ecology of the temperate Zones, University of Göttingen, Germany

6. Systematic Botany and Functional Biodiversity, Institute of Biology, Leipzig University, Leipzig, Germany

7. Senckenberg Biodiversity and Climate Research Centre (SBiK-F), Frankfurt, Germany

8. Harvard Forest, Harvard University, MA, USA

9. Biology Department, University of Washington, Seattle, USA

10. Swiss Federal Research Institute WSL, Birmensdorf, Switzerland

11. Chair of Silviculture, Faculty of Environment and Natural Resources, University of Freiburg, Germany

12. UFZ - Helmholtz-Centre for Environmental Research, Department of Soil Ecology, Halle (Saale), Germany

13. German Centre for Integrative Biodiversity Research (iDiv) Halle-Jena-Leipzig, Leipzig, Germany 14. Institute of Evolutionary Ecology and Conservation Genomics, University of Ulm, Germany

15. Institute for Biochemistry and Biology, University of Potsdam, Germany

16. Heinz Sielmann Foundation, Gut Herbigshagen, Duderstadt, Germany

17. Field Station Fabrikschleichach, Department of Animal Ecology and Tropical Biology (Zoology III), Julius-Maximilians-University Würzburg, Rauhenebrach, Germany

18. Bavarian Forest National Park, Grafenau, Germany 
36 19. Forest Botany and Tree Physiology, University of Göttingen,Germany

37 20. Institute of Zoology, DIB, University of Natural Resources and Life Sciences, Vienna, Austria

38 21. Ecology Group, Institute of Biology, Humboldt-Universität zu Berlin, Berlin, Germany

39 22. Max-Planck Institute for Biogeochemistry, Jena, Germany

40 23. Department of Geography, University of Zurich, Switzerland

41 24. Smithsonian Tropical Research Institute, Balboa Ancón, República de Panamá

42

43 Running title: Effects of forest features on communities

44 Keywords: land-use, global change, temperate forests, Biodiversity Exploratories, forest management,

45 multidiversity, specialisation, dark diversity

46 Type of article: Letters

47 Number of words: abstract: 150 - main text: 4995

48 Number of references: 75

49 Number of figures, tables, text boxes: 2 figures, 1 table, 0 text boxes

50 Correspondence to: Caterina Penone, tel: +41 31631 4926, caterina.penone@gmail.com

51 Statement of authorship: CP, EA and MF designed the study; CP analysed the data with insight from

52 EA, SSo,MF, RDM, CFD, MFL, PS; CP wrote the paper with substantial contribution of EA, SSo,

53 MF, SSe, NKS, FvdP, PM, MMG, CFD, PS. All authors except CP, EA, SSo, MFL, PM, SSe, CFD,

54 RDM, FvdP, JCM provided data. All authors revised the paper.

55 Data accessibility statement: The data will be made publicly available on the BExIS platform

56 (https://www.bexis.uni-jena.de/). 


\section{Abstract}

58 While forest management strongly influences biodiversity, it remains unclear how the structural and 59 compositional changes caused by management affect different community dimensions (e.g. richness, 60 specialisation, abundance or completeness) and how this differs between taxa. We assessed the effects 61 of nine forest features (representing stand structure, heterogeneity and tree composition) on thirteen 62 above- and belowground trophic groups of plants, animals, fungi and bacteria in 150 temperate forest 63 plots differing in their management type. Canopy cover decreased light resources, which increased 64 community specialisation but reduced overall diversity and abundance. Features increasing resource 65 types and diversifying microhabitats (admixing of oaks and conifers) were important and mostly 66 affected richness. Belowground groups responded differently to those aboveground and had weaker 67 responses to most forest features. Our results show that we need to consider forest features rather than 68 broad management types and highlight the importance of considering several groups and community

69 dimensions to better inform conservation. 
71 Land-use is among the strongest drivers of biodiversity loss (Foley et al. 2005; Flynn et al. 2009;

72 Newbold et al. 2015). In temperate forests, management can involve various elements, including 73 removal of timber and deadwood, the introduction of non-native trees and/or the promotion of a few 74 productive tree species (Bengtsson et al. 2000; McGrath et al. 2015; Chaudhary et al. 2016). Several studies have examined management effects on forest communities, however they generally consider only a limited number of taxa, mostly aboveground, and typically focus on species richness alone (reviewed in Paillet et al. 2010; Chaudhary et al. 2016). However, different taxa, and community dimensions other than richness, might show contrasting responses to management (Flynn et al. 2009; Paillet et al. 2010; Aubin et al. 2013). It is important to quantify and understand this potential variation in responses to determine the ecological mechanisms by which management affects communities and to guide conservation decisions (Aubin et al. 2013; Simons et al. 2016). To achieve a comprehensive understanding of the effects of forest management on biodiversity we need to "unpack" communities by considering responses of a range of community dimensions and taxa, including those belowground, which represent a large proportion of biodiversity and play fundamental roles in ecosystem functioning.

Most studies examining the effects of forest management on biodiversity have compared biodiversity between general management types (Paillet et al. 2010; Chaudhary et al. 2016). Whilst this provides information about specific management regimes, it makes comparisons complicated, as management varies substantially between countries and regions. It also makes it challenging to link effects of management to ecological theory, which typically considers more general mechanisms such as the role of resource availability and environmental heterogeneity in shaping communities (Stevens \& Carson 2002; Cadotte et al. 2017). To explore the mechanisms by which forest management affects biodiversity, we therefore need to focus on how management changes various forest features. 
To promote timber production, forest managers modify several features, such as tree species composition, stand age and density, or deadwood amounts (Bengtsson et al. 2000; Seidl et al. 2011; Schall \& Ammer 2013). These modifications directly affect the amount, type and heterogeneity of resources or microhabitats, as well as abiotic conditions, all of which can strongly affect forest communities (Duguid \& Ashton 2013; Chamagne et al. 2016; Zellweger et al. 2016, see detail in Table 1). The effects of some forest features on particular taxa are starting to be understood (Table 1), however, a clear link with management is still lacking (but see Schall et al. 2018) and the mechanisms communities.

Species richness is a key measure in both conservation and functional ecology research, however, it does not fully characterise communities (Wilsey et al. 2005; Lyashevska \& Farnsworth 2012). Another important community dimension is total abundance, which may respond differently to environmental drivers (Table 1) (Haddad et al. 2001; Pärtel et al. 2011; Purschke et al. 2013). Alongside the number and abundance of species, the characteristics of species present can vary strongly with management (Devictor et al. 2008; Simons et al. 2016). Species which are restricted to forest habitats, i.e., forest specialists, may be most sensitive to management changes (e.g. Fuller et al. 2008), and preserving forest specialists is likely to be of central concern for conservation (Paillet et al. 2010; Lange et al. 2014). A further relevant community dimension is the proportion of species that could potentially be present, based on their environmental requirements, but are missing from a community due to dispersal limitation (Lewis et al. 2017). This "dark diversity" can be used to estimate how far a given community is from its potential diversity, i.e. its "completeness" (Pärtel et al. 2011). 118 In general, we would expect species richness to be mostly related to the heterogeneity of resources and 
habitat, abundance to resource availability, forest specialisation to features defining the particular environmental conditions present in forests (e.g. light levels), and completeness to features linked to dispersal limitation (Table 1).

To achieve a comprehensive understanding of the drivers of forest diversity we need to consider a whole range of trophic groups (Seibold et al. 2018), which might respond differently to particular forest features. For instance, autotrophs should mostly respond to features affecting light levels and saproxylic species to deadwood (see detailed hypotheses in Table 1). Our knowledge of belowground responses is particularly limited. Where studied, it appears that these groups are mainly affected by soil conditions (Goldmann et al. 2015; Kaiser et al. 2016) and their responses to management may not necessarily mirror those of aboveground groups (Allan et al. 2014). However, we can hypothesize that belowground groups could respond to tree species identity and diversity if they form specialised, symbiotic or parasitic relationships with trees (e.g. fungi), or if trees differ in their litter chemistry and effects on soil properties (Gömöryová et al. 2013; Goldmann et al. 2015, 2016, Table 1).

We investigated the effects of forest features on multiple community dimensions, using a unique dataset that includes 13 above- and below-ground trophic groups of organisms in 150 German temperate forest plots. We examined the effects of forest features related to stand composition (percentage of dominant species), structure (mean tree size, canopy cover and deadwood volume) and heterogeneity (vertical and horizontal heterogeneity, tree and deadwood diversity) on four community dimensions: species richness, abundance, specialisation and completeness. Our main hypotheses are that, i) community dimensions respond differently to forest management, with richness and specialisation being most sensitive to heterogeneity and abundance to resources, ii) aboveground organisms respond strongly to management while belowground ones respond mainly to soil factors, and iii) forest features associated with an increase in the availability and heterogeneity of resources generally enhance all community dimensions. 


\section{Methods}

145 We studied 150 forest sites located in three regions in the southwest, centre and northeast of Germany, which form part of the large-scale Biodiversity Exploratories project (Fischer et al. 2010). The three

147 regions differ in climatic, geological and topographical conditions, with mean annual temperatures 148 ranging from $6-8 \cdot 5^{\circ} \mathrm{C}$ and mean annual precipitation from $500-1,000 \mathrm{~mm}$ (Fischer et al. 2010).

In each region, fifty $100 \times 100 \mathrm{~m}$ forest plots were installed within larger management units.

150 Plots were selected from a larger number of candidate plots to minimise variation in environmental 151 characteristics, whilst covering a representative range of forest management types and intensities (see 152 details in Fischer et al. 2010). The dominant tree species were European beech (Fagus sylvatica, 153 present in $69.3 \%$ of plots), and to a lesser extent, Norway spruce (Picea abies; $10.6 \%$ ), Scots pine 154 (Pinus sylvestris; 10.0\%) and two oak species (Quercus robur and Q. petraea; 4.6\%). These forests represent common lowland forest types in western and central Europe, which are dominated by a few broadleaf species (mostly beech). The two conifers are native to Central Europe but would not grow in the study regions under natural conditions (spruce) or would be less frequent (pine). However, they have been cultivated in the study regions for approximately 250 years. Oaks would also be less frequent under natural conditions. The studied forests can be classified into three broad management types: (i) unmanaged broadleaf (16\% of the 150 plots); (ii), managed broadleaf (even-aged: $50 \%$, uneven-aged $8 \%$ ); and (iii) managed conifer (even-aged: $26 \%$ ).

\section{Forest features}

164 Forest features were measured during a comprehensive forest inventory between 2008 and 2010. In each plot, all trees with a diameter at breast height $(\mathrm{DBH})>7 \mathrm{~cm}$ were surveyed and plots were scanned using terrestrial LIDAR (Appendix SA2 in Supporting Information). From this inventory, we calculated three measures of stand properties (canopy cover, mean DBH, and deadwood volume), four of stand heterogeneity (tree diversity, horizontal and vertical heterogeneity in stand structure and 
169 diversity in deadwood decay stage and origin) and two of stand composition (proportion of conifers 170 and oaks in the plot). All features were weakly correlated with each other (Spearman $\rho<|0.6|$, Appendix 171 Fig. S1). (PC) of an analysis combining soil information across the three regions: $\mathrm{pH}$, texture, moisture, nutrients (nitrogen, phosphorus and sulphur) and organic and inorganic carbon (Appendix Fig. S2, 175 Table S1).

\section{Species richness and abundance}

178 We measured richness (of species or operational taxonomical units, OTUs) and abundance for multiple taxa using established methods for each taxon (Appendix SA2). Aboveground groups were assessed between 2007-2009 and included understorey vascular plants and shrubs (hereafter "plants"), bryophytes, lichens, fungi on deadwood, arthropods (Araneae, Coleoptera, Hemiptera, Hymenoptera, Neuroptera, Orthoptera, Opiliones), birds and bats. Belowground groups (bacteria and soil fungi) were sampled in 2011 and analysed using pyrosequencing (richness) and soil phospholipid fatty acids (abundance) (Goldmann et al. 2016; Richter et al. 2018). In total, we had complete information for all taxa, environmental and forest features for 142 of the 150 plots.

To consider the functional role of the organisms in the ecosystem, we classified the taxa into 13 trophic/functional groups (sensu Seibold et al. 2018). Arthropods were classified into decomposers, 188 herbivores, omnivores and carnivores. Insectivorous birds and bats were classed as vertebrate 189 carnivores. Soil fungi were separated into three groups (mycorrhizal symbionts, saprotrophs and 190 pathogens) using FunGuild (Nguyen et al. 2016). Plants, bryophytes and lichens were considered as separate groups as they all can respond differently to forest features. We kept bacteria as a single group because we did not have information on bacterial functions. We then calculated richness and abundance for each of the 13 trophic groups. 
A measure of overall ecosystem richness can be useful for addressing general trends (e.g. for conservation purposes) in addition to studying individual responses of the various trophic groups. We therefore calculated overall ecosystem richness (multidiversity sensu, Allan et al. 2014), by scaling richness values of each trophic group to the maximum observed across all plots and calculating the average across groups. In this metric all groups are weighted equally, thus preventing the measure from being driven by speciose groups such as bacteria (Allan et al. 2014). We also calculated multiabundance in an analogous manner to multidiversity. We computed multidiversity and multiabundance for above- and belowground groups, separately and combined.

\section{Forest specialisation}

204 Literature data on forest specialisation is only available for a small subset of organisms. To obtain a comparable metric of forest specialisation for all species recorded in our study, we calculated the extent to which each species was a forest specialist (i.e. occurring primarily in forests) versus a habitat generalist (occurring equally in grasslands and forests). We did this by matching our forest data with data on the same groups, measured in 150 grasslands in the same regions (Fischer et al. 2010; Gossner et al. 2016; Soliveres et al. 2016). We used the forest and grassland datasets to calculate an index of forest specialisation $\left(F S_{i}\right)$ for each species $i$ based on its frequency in forests and grasslands: $F S_{i}=\left(n F_{i}\right.$ $\left./ n F_{\text {plots }}\right) /\left(\left(n F_{i} / n F_{\text {plots }}\right)+\left(n G_{i} / n G_{\text {plots }}\right)\right)$. Where $n F_{i}$ and $n G_{i}$ are the number of forest and grassland 212 plots respectively, where species $i$ occurred. $n F_{\text {plots }}$ and $n G_{\text {plots }}$ are the total number of forest and 213 grassland plots, respectively. The index of forest specialisation ranges between 1 for complete forest 214 specialists and 0 for complete grassland specialists, it is 0.5 for habitat generalists. For lichens, 215 bryophytes and vascular plants we used information from a total of 654, 1816 and 3000 plots, 216 respectively, in forests and grasslands in the same study regions (Boch et al. 2013a, 2016; Socher et 217 al. 2013). 
219 each plot by averaging the individual species specialisation values $\left(F S_{i}\right)$. Because mean specialisation

220 is scaled between 0 and 1, and thus comparable between groups, we calculated overall community 221 specialisation (multispecialisation) for each plot by simply averaging the specialisation values of 222 multiple trophic groups. Deadwood fungi were excluded from this analysis as we did not have any 223 information for this group from grasslands.

A comparison of $F S_{i}$ with literature data for plants, birds, beetles, spiders and hymenopterans confirmed that our measure reflects species specialisation to forests (Appendix Fig. S3,S4). However, note that $F S_{i}$ might describe specialisation to managed beech forests, as this is the dominant forest type in our dataset. In addition, while forests and grasslands represent important land cover types in the three regions (Fischer et al. 2010), our measure does not include other habitats such as hedgerows, urban areas, croplands or wetlands, and therefore should not be considered as an absolute, but rather a relative, measure of species specialisation to forests. Finally, we tested whether increases in community specialisation were linked to species richness and if they were due to an increase in the proportion of specialists or a decrease in generalists (Appendix Fig.S5, S6).

Dark diversity and community completeness

We considered as missing, i.e. belonging to dark diversity, all the species that were absent from a given plot but had a probability of occurrence in the plot that exceeded a threshold value. We estimated the probability that a given species occurs in a given plot by calculating Beals' probabilities (Beals 1984). 238 As this method is considered unreliable for species that do not show strong associations with any others, we filtered out such species using the randomisation approach of De Cáceres \& Legendre 240 (2008) with 500 permutations. This process also removed most of the rare species (final $\mathrm{n}=2690$, i.e. $26 \%$ of all species) for which there is insufficient information to calculate occurrence probabilities (De

242 Cáceres \& Legendre 2008). We calculated Beals’ probabilities separately for each group and each 
region and we only tested for co-occurrences between species from the same group, e.g. only between

244 plants, but not between plants and herbivores. We then defined a threshold probability of occurrence separately for each group, as the 5\% quantile of probabilities of occurrence across all plots (Lewis et al. 2016).

We calculated community completeness as the log-ratio of richness and dark diversity (as defined in Pärtel 2014; Lewis et al. 2016, 2017). It has only been shown that plant communities dominated by species with low dispersal ability had higher dark diversity (Riibak et al. 2017). We also checked whether this relationship held for arthropods, using data on dispersal abilities from literature (Gossner et al. 2015). Communities that had more species with good dispersal abilities were more complete (Pearson r=0.77, p<0.001, Appendix Fig. S7) and had lower dark diversity ( $\mathrm{r}=-0.31$ $\mathrm{p}<0.001$ ), thus confirming that for arthropods too, dark diversity is related to dispersal limitation. Results based on completeness calculated with a broad (0\%) and narrow (10\%) threshold, as suggested by Lewis et al. (2016), were also consistent with the ones reported here (Appendix Fig. S8).

All the community dimensions contributed complementary information. Richness and completeness were the most closely related dimensions (Spearman $\rho: 0.6$ ), all other pairwise correlations between dimensions were lower than $|0.45|$ (Appendix Fig. S9).

\section{Effects of forest features on forest communities}

We fitted linear models and checked model assumptions for each group and community 262 dimension separately. We standardized all variables (mean=0 and $s d=1$ ), to be able to compare effect sizes between the predictors. We accounted for soil characteristics by including the first two axes of the PCA as covariates in all models. To account for regional differences, we calculated residuals for all our variables (soil PC, forest features and community dimensions) from linear models including region, and we used these residual values in all analyses. To assess which trophic groups were most strongly affected by forest features, we calculated the average of absolute total effects for each group 
268 across all forest features, inverse weighted by their standard errors (i.e. variables with higher standard 269 errors had less influence on the average).

The effects of forest features on richness might be mediated by changes in abundance.

271 Therefore, we also ran the same models with the residuals of richness as the response variable, i.e. 272 after correcting richness for abundance. Given that the proportion of conifers included both pines and 273 spruces, we also analysed their effects separately.

Variance inflation factors (VIF) showed that all our variables had $\mathrm{VIF}<3$, hence there was no multicollinearity in the models (Fox \& Weisberg 2011). Using generalised additive models (GAM; Wood 2011), we did not find evidence for potential non-linear relationships. We tested for residual spatial autocorrelation using Moran's I tests. To reduce potential type I errors associated with multiple testing while minimising type II errors, we controlled for false discovery rates (FDR) using a Benjamini-Hochberg procedure with a threshold of 0.2 (Verhoeven et al. 2005). To assess whether our results were influenced by differences in detectability between groups, we calculated sampling coverage using the iNEXT package in $\mathrm{R}$ (Hsieh et al. 2016) and verified if sampling coverage was performed all analyses using R v.3.4.3 (R Core Team 2017). abundance and -completeness (grey panels, Fig. 1), they were often in the opposite direction for multispecialisation (white panels, Fig. 1). In particular, higher canopy cover reduced richness, 
293 was the dimension that responded most frequently to the forest features $(23 \%$ of significant 294 relationships out of 117 tests across all groups, or $16 \%$ when corrected by abundance, Fig. 1 and 295 Appendix Fig. S10), followed by completeness (17\% of 117 tests), specialisation (14\% of 108 tests) 296 and abundance (13\% of 90 tests). There were few effects on the specialisation of arthropod carnivores, 297 omnivores and decomposers, bryophytes and symbionts because almost all species in these groups 298 were specialist (specialisation index close to 1, Appendix Fig. S3). For most groups, an increase of the 299 community specialisation is linked to an increase in the proportion of specialists in the community.

300 However, for soil fungi saprotrophs and pathogens it might be due to a decrease in generalists 301 (Appendix Fig.S5).

Response of the trophic groups to forest features

304 Every trophic group was significantly associated with several forest features (mean: $2.1 \pm 1.1 \mathrm{sd}$. 305 features) with an absolute weighted mean effect of $0.11( \pm 0.03)$ across all community dimensions and 306 forest features ("mean effect" column in Fig. 2). The groups that responded significantly to most forest 307 features were deadwood fungi (mean across all dimensions: $3.5 \pm 0.7$ ), vertebrate carnivores (3.3 \pm 1.5 ),

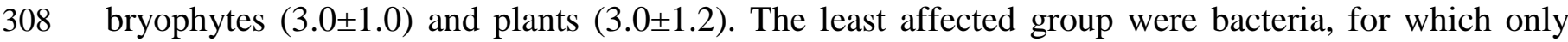
309 conifer cover was significant. However, this group includes different trophic groups having potentially 310 contrasting responses. Our models generally explained more variation for above than for belowground 311 groups (Appendix SA5).

\section{Relative importance of forest features}

314 The two measures of stand composition (proportion of conifers and oaks) and canopy cover had the 315 strongest and most contrasting effects across all dimensions and trophic groups (Fig. 2). Most other 316 forest features had consistent trends across the 13 groups but had fewer significant effects (all blue or 317 all red columns in Fig. 2, Appendix Fig.S11). 
319 the four community dimensions aboveground. However, we only found one significant effect of tree

320 diversity on richness (of saprotrophic fungi) and just a few positive effects of deadwood diversity (e.g. 321 on deadwood fungi or vertebrates).

Among other structure measures, mean DBH, representing stand age (Fig. S1), had only a few positive effects on higher trophic levels and deadwood volume had almost no effects on community dimensions (Fig.2). Finally, soil properties affected belowground groups more strongly than aboveground ones (Fig.2). The second component of the soil PCA (expressing variation in carbon, phosphorus, and texture) was an important predictor of soil groups. Variation in the first component had mostly been accounted for when correcting for regional differences. generally consistent, they were opposed to each other in only one case (arthropod herbivore completeness, Appendix Fig.S12). The effects of the various forest features also remained unchanged when multidiversity was calculated using different methods (Appendix Fig.S13). Spatial autocorrelation did not affect our results (Appendix Tables S3,S4) and so we present the results of the simpler models. Only in four of 99 cases could the results of richness and completeness have been driven by higher sampling coverage (richness: effect of conifer cover on decomposers and bryophytes and effect of oak cover on vascular plants; completeness: effect of conifer cover on arthropod decomposers, Appendix Fig. S14).

Our parallel analysis using broad management types instead of forest features showed that forest communities did not differ between management types when considering all dimensions and groups together (Appendix Fig. S15,S16). In general, models using forest features explained more variation than models using management types for all dimensions and trophic groups (except bacteria, Appendix Fig.S17). Furthermore, different management types can lead to similar levels of forest features (e.g. deadwood volume, Appendix Fig. S16). 


\section{Discussion}

Differences between community dimensions

345 Despite the large effort devoted to understanding how forest management affects biodiversity, few 346 studies have compared effects across taxa and community dimensions to gain a comprehensive 347 understanding of how different forest features affect communities (Table 1). Our analysis of 13 above348 and belowground trophic groups showed that different community dimensions varied in their response 349 to a range of forest features. Richness was most sensitive to changes in forest features but some of 350 these effects were driven by abundance. Abundance and completeness responded similarly but to fewer 351 features. In contrast, forest specialisation generally had opposing responses to the other three 352 dimensions (Fig. 1). While our forest specialisation measure may have its limitations (see methods section), this result is of major importance for understanding biodiversity change because it implies that measures targeting overall richness may fail to protect communities that depend upon particular forest habitats (Devictor \& Robert 2009; Pellissier et al. 2017).

Differences between above and belowground groups

358 Generally, aboveground trophic groups responded similarly to the forest features. However, in most cases, responses of belowground groups did not mirror those aboveground, as also found in grasslands

360 (Allan et al. 2014). For instance, we found stronger effects of canopy cover on aboveground than on belowground groups, perhaps because aboveground groups are directly affected by understorey light 362 levels while soil organisms respond to other factors. Indeed, as predicted, belowground groups were mainly affected by soil conditions and tree identity (Goldmann et al. 2016; Kaiser et al. 2016; Richter et al. 2018). Increasing belowground diversity through changing forest management might therefore be more challenging than for aboveground organisms. However, our results show that admixing with oaks, would benefit both above- and belowground groups in beech-dominated stands. 
369 Forest features explained community patterns better than broad management types, as suggested before 370 (Duguid \& Ashton 2013; Gossner et al. 2014). Species composition of the stand was the most 371 important predictor across community dimensions. Increasing oak cover had generally positive effects 372 across community dimensions and trophic groups: particularly on richness but surprisingly not on abundance. The presence of unique microhabitats in oak stands might increase richness by favouring species with specialised niches (Vuidot et al. 2011, Table 1), and oaks are generally known to support high richness of several arthropod taxa (Brändle \& Brandl 2001; Müller \& Gossner 2007). Mixing oak litter with beech litter could also have beneficial effects on belowground groups, as it reduces litter packing and neutralises soil acidity (Godefroid et al. 2005). Increasing the proportion of oaks in the stand is therefore beneficial for diversity as it increases richness without reducing specialisation, likely by enhancing both generalist and specialist species. In beech-dominated forests, admixture of other trees increases the number and amount of resources and microhabitats for certain species, suggesting that shifting away from pure beech stands to mixed broadleaf stands might increase biodiversity. Increasing conifer cover generally promoted species richness but decreased community specialisation across most trophic groups (Fig.2). Coniferous stands therefore contained communities with large proportions of generalists, with broad habitat niches, which may be of low conservation interest (Julliard et al. 2004; Colles et al. 2009). In beech-dominated landscapes, increasing conifer cover might increase species richness because conifers add unique resource types and microhabitats (Table 1). We did not find evidence for non-linear effects of conifer cover but in forests dominated by broadleaf trees other than beech, there is evidence that mixed conifer/broadleaf forests have higher diversity than pure conifer stands (Felton et al. 2010). In contrast, and conifer cover increased the specialisation of lichens, bacteria and symbionts but reduced their richness, suggesting that species associated with conifers are rarely found in non-forest habitats (Király et al. 2013; Tedersoo et al. 2014). The completeness of belowground groups tended to decline with conifer cover while richness 
was unaffected. Certain species may therefore be excluded from conifer stands due to increased competition, loss of particular niches, or growth limitation by allelopathic compounds (Fahrig \& Triantis 2013; Moeslund et al. 2017). Our results clearly show that changes in tree species composition have major effects on forest communities, with effects on most groups and all different dimensions.

\section{Effects of stand structure on community dimensions}

The only measure of stand structure that had a large effect across groups was canopy cover, strongly suggesting that light conditions are a major, general driver of forest communities. Aboveground groups tended to decline in diversity, abundance and completeness with increasing canopy cover, while their specialisation increased. These contrasting effects of canopy cover are largely responsible for the differing responses of richness and specialisation and agree with previous studies showing that high light levels increased understorey plant richness and abundance but decreased forest specialisation deadwood volume had very few effects on diversity. This was surprising as previous studies have abundance. These negative trends could be related to direct effects of decreased solar radiation and temperature (Salmon et al. 2008; Henneron et al. 2017), or to cascading effects due to the decline in vascular plant species richness, abundance and composition (Henneron et al. 2017), although future analyses would be needed to separate these potential mechanisms. Light conditions might also partially underlie some of the effects of tree species composition since the canopies of oaks and some conifers (e.g. Scots pines) are typically more open than those of beech stands, which could explain the decrease of forest specialist plants in conifer stands (Canham et al. 1994; Boch et al. 2013b).

In contrast to canopy cover, mean tree size (or stand age; both captured by mean DBH) and shown positive effects of stand age and deadwood on biodiversity (Table 1). It could be because we did not measure very old stands, which are rare in Central European production forests, and which would have higher levels of deadwood and tree cavities due to senescent trees, typical of primeval 
418 forests (Christensen et al. 2005). However, stand age effects are thought to operate through greater

419 heterogeneity and dead wood availability in older stands (Lassauce et al. 2013) and, as it is likely that

420 these effect were captured by our composition and heterogeneity measures, stand age per se may not

421 a major driver of forest communities.

Effects of stand heterogeneity on community dimensions

We expected within-stand heterogeneity to increase richness because the increased niche diversity should allow more species to coexist (Stein et al. 2014). However, heterogeneity-related

forest features had few effects on our forest communities, exceptions being an increase in deadwood

427 fungal richness and completeness with increasing deadwood diversity and some effects of horizontal and vertical heterogeneity on bryophyte and lichen communities. The general lack of effects of vertical or horizontal heterogeneity, or tree diversity, might be because species respond to heterogeneity at

430 larger scales, meaning that increasing heterogeneity at the plot scale would not affect communities if 431 the landscape remains homogeneous (Schall et al. 2018), or because there was not sufficient variation 432 in heterogeneity between our plots. For instance, tree diversity is relatively low, because all our forests 433 (including the unmanaged ones) have a history of management and because the main forest types in 434 Central Europe are dominated by one or two tree species (Fischer et al. 2010). The positive effects of conifers and oaks suggest beneficial effects of mixing beech with other species. However, to further test the role of heterogeneity, future studies should compare the effects of a larger gradient in diversity, 437 e.g. by doing similar studies in temperate regions with higher tree richness, or in highly diverse 438 subtropical or tropical forests.

440 Conclusions

441 Our study was able to identify the specific forest features that drive different dimensions of biodiversity 442 above and belowground. Consistent with our hypothesis, features that decreased light availability 
443 (canopy cover) generally decreased abundance and diversity but favoured specialists. Features that 444 increased niche diversity by diversifying resources and microhabitats (oak and conifer cover) were 445 important drivers and mostly affected richness. Finally, aboveground organisms responded strongly to 446 the forest features while belowground ones were mainly driven by soil factors. Since these forest 447 features can be modified individually through management, our results open up the possibility of fine448 tuning forest management to maintain both species-rich forests and to conserve specialist-rich 449 communities. Our results suggest that it may not always be possible to realise this within a single stand, 450 given the contrasting responses of specialisation and richness to stand level features, which could argue 451 for increasing forest diversity at larger spatial scales (van der Plas et al. 2016; Schall et al. 2018). Our 452 results clearly show that it is essential to "unpack" both management and diversity while exploring the 453 relationships between biodiversity and complex forest management practices. Such approaches can 454 help to fine-tune management interventions to maintain and promote biodiversity in anthropogenic 455 landscapes. 


\section{Acknowledgements}

457 We thank Stefan Blaser, Rolf Daniel, Jessica Heublein, Tiemo Kahl, Kristin Kaiser, Theresa

458 Kloetzing, Markus Lange, Esther Pasalic, Susan Trumbore and Manfred Türke for providing data.

459 We are grateful to Carsten F. Dormann and two anonymous reviewers for constructive comments on

460 earlier drafts of this paper. We also thank the managers of the Exploratories, Konstans Wells, Sonja

461 Gockel, Andreas Hemp and Martin Gorke for their work in maintaining the plot and project

462 infrastructure; Christiane Fischer for giving support through the central office, Andreas Ostrowski

463 for database management, and Eduard Linsenmair, Dominik Hessenmöller, Ernst-Detlef Schulze and

464 the late Elisabeth Kalko for their role in setting up the Biodiversity Exploratories. The work was

465 partly funded by the DFG Priority Program 1374 "Infrastructure-Biodiversity-Exploratories" (DFG-

466 Refno. Po362/18-3). Fieldwork permits were issued by the responsible state environmental offices of

467 Baden-Württemberg, Thüringen, and Brandenburg (according to $§ 72$ BbgNatSchG). SSo was

468 supported by the Spanish Government under a Ramón y Cajal contract (RYC-2016-20604). 
Allan, E., Bossdorf, O., Dormann, C.F., Prati, D., Gossner, M.M., Tscharntke, T., et al. (2014). Interannual variation in land-use intensity enhances grassland multidiversity. Proc. Natl. Acad. Sci., 111, 308-313.

Aubin, I., Venier, L., Pearce, J. \& Moretti, M. (2013). Can a trait-based multi-taxa approach improve our assessment of forest management impact on biodiversity? Biodivers. Conserv., 22, 29572975 .

Beals, E.W. (1984). Bray-Curtis ordination: An effective strategy for analysis of multivariate ecological data. Adv. Ecol. Res., 14, 1-55.

Bengtsson, J., Nilsson, S.G., Franc, A. \& Menozzi, P. (2000). Biodiversity, disturbances, ecosystem function and management of European forests. For. Ecol. Manage., 132, 39-50.

Boch, S., Prati, D., Hessenmöller, D., Schulze, E.-D. \& Fischer, M. (2013a). Richness of lichen species, especially of threatened ones, is promoted by management methods furthering stand continuity. PLoS One, 8, e55461.

Boch, S., Prati, D., Müller, J., Socher, S., Baumbach, H., Buscot, F., et al. (2013b). High plant species richness indicates management-related disturbances rather than the conservation status of forests. Basic Appl. Ecol., 14, 496-505.

Boch, S., Prati, D., Schöning, I. \& Fischer, M. (2016). Lichen species richness is highest in nonintensively used grasslands promoting suitable microhabitats and low vascular plant competition. Biodivers. Conserv., 25, 225-238.

Brändle, M. \& Brandl, R. (2001). Species richness of insects and mites on trees: expanding Southwood. J. Anim. Ecol., 70, 491-504.

Brunet, J., Fritz, Ö. \& Richnau, G. (2010). Biodiversity in European beech forests - a review with recommendations for sustainable forest management. Ecol. Bull., 53, 77-94.

De Cáceres, M. \& Legendre, P. (2008). Beals smoothing revisited. Oecologia, 156, 657-669. 
Cadotte, M.W., Barlow, J., Nuñez, M.A., Pettorelli, N. \& Stephens, P.A. (2017). Solving environmental problems in the Anthropocene: the need to bring novel theoretical advances into the applied ecology fold. J. Appl. Ecol., 54, 1-6.

Canham, C.D., Finzi, A.C., Pacala, S.W. \& Burbank, D.H. (1994). Causes and consequences of resource heterogeneity in forests: interspecific variation in light transmission by canopy trees. Can. J. For. Res., 24, 337-349.

Chamagne, J., Paine, C.E.T., Schoolmaster, D.R., Stejskal, R., Volarř́ík, D., Šebesta, J., et al. (2016). Do the rich get richer? Varying effects of tree species identity and diversity on the richness of understory taxa. Ecology, 97, 2364-2373.

Chaudhary, A., Burivalova, Z., Koh, L.P. \& Hellweg, S. (2016). Impact of Forest Management on Species Richness: Global Meta-Analysis and Economic Trade-Offs. Sci. Rep., 6, 1-10.

Christensen, M., Hahn, K., Mountford, E.P., Ódor, P., Standovár, T., Rozenbergar, D., et al. (2005). Dead wood in European beech (Fagus sylvatica) forest reserves. For. Ecol. Manage., 210, 267282.

Colles, A., Liow, L.H. \& Prinzing, A. (2009). Are specialists at risk under environmental change? Neoecological, paleoecological and phylogenetic approaches. Ecol. Lett., 12, 849-863.

Devictor, V., Julliard, R. \& Jiguet, F. (2008). Distribution of specialist and generalist species along spatial gradients of habitat disturbance and fragmentation. Oikos, 117, 507-514.

Devictor, V. \& Robert, A. (2009). Measuring community responses to large-scale disturbance in conservation biogeography. Divers. Distrib., 15, 122-130.

Duguid, M.C. \& Ashton, M.S. (2013). A meta-analysis of the effect of forest management for timber on understory plant species diversity in temperate forests. For. Ecol. Manage., 303, 81-90.

Fahrig, L. \& Triantis, K. (2013). Rethinking patch size and isolation effects: the habitat amount hypothesis. J. Biogeogr., 40, 1649-1663.

Felton, A., Lindbladh, M., Brunet, J. \& Fritz, Ö. (2010). Replacing coniferous monocultures with 
mixed-species production stands: An assessment of the potential benefits for forest biodiversity in northern Europe. For. Ecol. Manage., 260, 939-947.

521 Fischer, M., Bossdorf, O., Gockel, S., Hänsel, F., Hemp, A., Hessenmöller, D., et al. (2010). Implementing large-scale and long-term functional biodiversity research: The Biodiversity

Flynn, D.F.B., Gogol-Prokurat, M., Nogeire, T., Molinari, N., Richers, B.T., Lin, B.B., et al. (2009). Loss of functional diversity under land use intensification across multiple taxa. Ecol. Lett., 12, $22-33$.

Foley, J.A., DeFries, R., Asner, G.P., Barford, C., Bonan, G., Carpenter, S.R., et al. (2005). Global consequences of land use. Science, 309, 570-574.

Fox, J. \& Weisberg, S. (2011). An R companion to applied regression. Second edi. SAGE, Thousand Oaks, CA.

Fuller, R.J., Oliver, T.H. \& Leather, S.R. (2008). Forest management effects on carabid beetle communities in coniferous and broadleaved forests: implications for conservation. Insect Conserv. Divers., 1, 242-252.

Godefroid, S., Massant, W. \& Koedam, N. (2005). Variation in the herb species response and the humus quality across a 200-year chronosequence of beech and oak plantations in Belgium. Ecography, 28, 223-235.

Goldmann, K., Schoning, I., Buscot, F. \& Wubet, T. (2015). Forest management type influences diversity and community composition of soil fungi across temperate forest ecosystems. Front. Microbiol., 6, 1300.

Goldmann, K., Schröter, K., Pena, R., Schöning, I., Schrumpf, M., Buscot, F., et al. (2016). Divergent habitat filtering of root and soil fungal communities in temperate beech forests. Sci. Rep., 6, 31439.

Gömöryová, E., Ujházy, K., Martinák, M. \& Gömöry, D. (2013). Soil microbial community response 
to variation in vegetation and abiotic environment in a temperate old-growth forest. Appl. Soil Ecol., 68, 10-19.

Gossner, M.M., Lewinsohn, T.M., Kahl, T., Grassein, F., Boch, S., Prati, D., et al. (2016). Land-use intensification causes multitrophic homogenization of grassland communities. Nature, 540, 266-269.

Gossner, M.M., Schall, P., Ammer, C., Ammer, U., Engel, K., Schubert, H., et al. (2014). Forest management intensity measures as alternative to stand properties for quantifying effects on biodiversity. Ecosphere, 5, art113.

Gossner, M.M., Simons, N.K., Achtziger, R., Blick, T., Dorow, W.H.O., Dziock, F., et al. (2015). A summary of eight traits of Coleoptera, Hemiptera, Orthoptera and Araneae, occurring in grasslands in Germany. Sci. Data, 2, 150013.

Haddad, N.M., Tilman, D., Haarstad, J., Ritchie, M. \& Knops, J.M.H. (2001). Contrasting effects of plant richness and composition on insect communities: a field experiment. Am. Nat., 158, 1735 .

Henneron, L., Aubert, M., Archaux, F., Bureau, F., Dumas, Y., Ningre, F., et al. (2017). Forest plant community as a driver of soil biodiversity: experimental evidence from collembolan assemblages through large-scale and long-term removal of oak canopy trees Quercus petraea. Oikos, 126, 420-434.

Hsieh, T.C., Ma, K.H. \& Chao, A. (2016). iNEXT: an R package for rarefaction and extrapolation of species diversity (Hill numbers). Methods Ecol. Evol., 7, 1451-1456.

Julliard, R., Jiguet, F. \& Couvet, D. (2004). Common birds facing global changes: what makes a species at risk? Glob. Chang. Biol., 10, 148-154.

Kaiser, K., Wemheuer, B., Korolkow, V., Wemheuer, F., Nacke, H., Schöning, I., et al. (2016). Driving forces of soil bacterial community structure, diversity, and function in temperate grasslands and forests. Sci. Rep., 6, 33696. 
569 Király, I., Nascimbene, J., Tinya, F. \& Ódor, P. (2013). Factors influencing epiphytic bryophyte and lichen species richness at different spatial scales in managed temperate forests. Biodivers. Conserv., 22, 209-223.

Lange, M., Türke, M., Pašalić, E., Boch, S., Hessenmöller, D., Müller, J., et al. (2014). Effects of forest management on ground-dwelling beetles (Coleoptera; Carabidae, Staphylinidae) in Central Europe are mainly mediated by changes in forest structure. For. Ecol. Manage., 329, $166-176$.

Lassauce, A., Larrieu, L., Paillet, Y., Lieutier, F. \& Bouget, C. (2013). The effects of forest age on saproxylic beetle biodiversity: Implications of shortened and extended rotation lengths in a French oak high forest. Insect Conserv. Divers., 6, 396-410.

Lewis, R.J., de Bello, F., Bennett, J.A., Fibich, P., Finerty, G.E., Götzenberger, L., et al. (2017). Applying the dark diversity concept to nature conservation. Conserv. Biol., 31, 40-47.

Lewis, R.J., Szava-Kovats, R. \& Pärtel, M. (2016). Estimating dark diversity and species pools: an empirical assessment of two methods. Methods Ecol. Evol., 7, 104-113.

Lyashevska, O. \& Farnsworth, K.D. (2012). How many dimensions of biodiversity do we need? Ecol. Indic., 18, 485-492.

McGrath, M.J., Luyssaert, S., Meyfroidt, P., Kaplan, J.O., Bürgi, M., Chen, Y., et al. (2015). Reconstructing European forest management from 1600 to 2010. Biogeosciences, 12, 42914316.

Moeslund, J.E., Brunbjerg, A.K., Clausen, K.K., Dalby, L., Fløjgaard, C., Juel, A., et al. (2017). Using dark diversity and plant characteristics to guide conservation and restoration. J. Appl. Ecol., 10.1111/13.

Müller, J. \& Gossner, M. (2007). Single host trees in a closed forest canopy matrix: A highly fragmented landscape? J. Appl. Entomol., 131, 613-620.

Newbold, T., Hudson, L.N., Hill, S.L.L., Contu, S., Lysenko, I., Senior, R.A., et al. (2015). Global 
effects of land use on local terrestrial biodiversity. Nature, 520, 45-50.

Nguyen, N.H., Song, Z., Bates, S.T., Branco, S., Tedersoo, L., Menke, J., et al. (2016). FUNGuild: An open annotation tool for parsing fungal community datasets by ecological guild. Fungal Ecol., 20, 241-248.

Paillet, Y., Archaux, F., Boulanger, V., Debaive, N., Fuhr, M., Gilg, O., et al. (2017). Snags and large trees drive higher tree microhabitat densities in strict forest reserves. For. Ecol. Manage., $389,176-186$.

Paillet, Y., Bergès, L., Hjältén, J., Ódor, P., Avon, C., Bernhardt-Römermann, M., et al. (2010). Biodiversity differences between managed and unmanaged forests: meta-analysis of species richness in Europe. Conserv. Biol., 24, 101-112.

Pärtel, M. (2014). Community ecology of absent species: Hidden and dark diversity. J. Veg. Sci., 25, 1154-1159.

Pärtel, M., Szava-Kovats, R. \& Zobel, M. (2011). Dark diversity: Shedding light on absent species. Trends Ecol. Evol., 26, 124-128.

Pellissier, V., Mimet, A., Fontaine, C., Svenning, J. \& Couvet, D. (2017). Relative importance of the land-use composition and intensity for the bird community composition in anthropogenic landscapes. Ecol. Evol., 7, 10513-10535.

van der Plas, F., Manning, P., Soliveres, S., Allan, E., Scherer-lorenzen, M., Wirth, C., et al. (2016). Biotic homogenization can decrease landscape-scale forest multifunctionality. Proc. Natl. Acad. Sci., 113, E2549-E2549.

Purschke, O., Schmid, B.C., Sykes, M.T., Poschlod, P., Michalski, S.G., Durka, W., et al. (2013). Contrasting changes in taxonomic, phylogenetic and functional diversity during a long-term succession: insights into assembly processes. J. Ecol., 101, 857-866.

R Core Team. (2017). R: A language and environment for statistical computing. R Foundation for Statistical Computing, Vienna, Austria. http://www.r-project.org. 
619 Richter, A., Schöning, I., Kahl, T., Bauhus, J. \& Ruess, L. (2018). Regional environmental conditions shape microbial community structure stronger than local forest management

Schall, P. \& Ammer, C. (2013). How to quantify forest management intensity in Central European forests. Eur. J. For. Res., 132, 379-396.

Schall, P., Gossner, M.M., Heinrichs, S., Fischer, M., Boch, S., Prati, D., et al. (2018). The impact of even-aged and uneven-aged forest management on regional biodiversity of multiple taxa in European beech forests. J. Appl. Ecol., 55, 267-278.

Seibold, S., Cadotte, M.W., MacIvor, J.S., Thorn, S. \& Müller, J. (2018). The necessity of multitrophic approaches in community ecology. Trends Ecol. Evol.

Seidl, R., Schelhaas, M.-J. \& Lexer, M.J. (2011). Unraveling the drivers of intensifying forest disturbance regimes in Europe. Glob. Chang. Biol., 17, 2842-2852.

Simons, N.K., Weisser, W.W. \& Gossner, M.M. (2016). Multi-taxa approach shows consistent shifts in arthropod functional traits along grassland land-use intensity gradient. Ecology, 97, 754-764.

Socher, S.A., Prati, D., Boch, S., Müller, J., Baumbach, H., Gockel, S., et al. (2013). Interacting effects of fertilization, mowing and grazing on plant species diversity of 1500 grasslands in Germany differ between regions. Basic Appl. Ecol., 14, 126-136.

Soliveres, S., van der Plas, F., Manning, P., Prati, D., Gossner, M.M., Renner, S.C., et al. (2016). Biodiversity at multiple trophic levels is needed for ecosystem multifunctionality. Nature, 536, $456-459$. 
644 Stein, A., Gerstner, K. \& Kreft, H. (2014). Environmental heterogeneity as a universal driver of species richness across taxa, biomes and spatial scales. Ecol. Lett., 17, 866-880.

Stevens, M.H.H. \& Carson, W.P. (2002). Resource quantity, not resource heterogeneity, maintains plant diversity. Ecol. Lett., 5, 420-426.

648 Tedersoo, L., Bahram, M., Põlme, S., Kõljalg, U., Yorou, N.S., Wijesundera, R., et al. (2014). 649 Global diversity and geography of soil fungi. Science, 346, 1256688.

Wood, S.N. (2011). Fast stable restricted maximum likelihood and marginal likelihood estimation of semiparametric generalized linear models. J. R. Stat. Soc. Ser. B (Statistical Methodol., 73, 336.

Zellweger, F., Baltensweiler, A., Ginzler, C., Roth, T., Braunisch, V., Bugmann, H., et al. (2016). Environmental predictors of species richness in forest landscapes: abiotic factors versus vegetation structure. J. Biogeogr., 43, 1080-1090. 


\section{Supporting information}

671 Additional Supporting Information may be downloaded via the online version of this article at Wiley

672 Online Library (www.ecologyletters.com).

673 As a service to our authors and readers, this journal provides supporting information supplied by the

674 authors. Such materials are peer-reviewed and may be re-organized for online delivery, but are not

675 copy-edited or typeset. Technical support issues arising from supporting information (other than

676 missing files) should be addressed to the authors.

677

678 


\begin{tabular}{|c|c|c|c|c|c|}
\hline Forest feature & Process & Richness & Abundance & $\begin{array}{l}\text { Forest } \\
\text { specialisation }\end{array}$ & Completeness \\
\hline & & $\begin{array}{l}\text { Mostly related to } \\
\text { resource and habitat } \\
\text { heterogeneity }\end{array}$ & $\begin{array}{l}\text { Mostly related to } \\
\text { resource } \\
\text { availability }^{1-3}\end{array}$ & $\begin{array}{l}\text { Mostly related to } \\
\text { features defining } \\
\text { the particular } \\
\text { environmental } \\
\text { conditions present } \\
\text { in forests }\end{array}$ & $\begin{array}{l}\text { Mostly related to } \\
\text { dispersal } \\
\text { limitation and } \\
\text { features at larger } \\
\text { spatial scale }^{6-8}\end{array}$ \\
\hline $\begin{array}{l}\text { Stand } \\
\text { properties/structure }\end{array}$ & $\begin{array}{l}\text { Change in resource or } \\
\text { microhabitat amount }\end{array}$ & & & & \\
\hline $\begin{array}{l}\text { Canopy cover } \\
\left(\mathrm{m}^{2} / \mathrm{ha}\right)\end{array}$ & $\begin{array}{l}\text { Decreases } \\
\text { light/radiation, and } \\
\text { temperature; increases } \\
\text { air and soil moisture } \\
\text { Increases temperature } \\
\text { buffering }^{14} \text {. Could } \\
\text { reduce dispersal of wind- } \\
\text { dispersed species }^{15}\end{array}$ & $\begin{array}{l}\downarrow \text { Autotrophs }{ }^{16-18}, \\
\text { fungi }^{19,20} \\
\downarrow \uparrow \text { Arthropods }{ }^{13,21-25} \text {, } \\
\text { vertebrate } \\
\text { carnivores }^{26-29} \text {, soil } \\
\text { fungi }^{30,31}\end{array}$ & $\begin{array}{l}\downarrow \text { Autotrophs }^{32}, \\
\text { fungi }^{20}, \\
\downarrow \uparrow \text { Soil fungi }^{30}, \\
\text { arthropods }^{23,33,34} \text {, } \\
\text { vertebrate } \\
\text { carnivores }^{35,36}\end{array}$ & $\begin{array}{l}\uparrow \text { Autotrophs } \\
\text { arthropods }^{38} \text {, } \\
\text { birds }^{29} \\
\text { ( } \uparrow) \text { Belowground } \\
\text { groups, fungi }\end{array}$ & 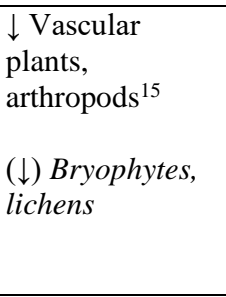 \\
\hline $\begin{array}{l}\text { Mean DBH: mean } \\
\text { diameter at breast } \\
\text { height }(\mathrm{cm})\end{array}$ & $\begin{array}{l}\text { Provides stable } \\
\text { conditions and longer } \\
\text { time for colonisation } \\
\text { (reducing dispersal } \\
\text { limitation), old trees } \\
\text { increase the amount of } \\
\text { microhabitats } \\
\end{array}$ & $\begin{array}{l}\uparrow \text { Aboveground } \\
\text { groups }^{39,43,44} \\
\text { ( } \uparrow) \text { Belowground } \\
\text { groups }^{43}\end{array}$ & $\begin{array}{l}\uparrow \text { Aboveground } \\
\text { groups }^{39} \\
\text { ( } \uparrow) \text { Belowground } \\
\text { groups }\end{array}$ & $\begin{array}{l}\uparrow \text { Aboveground } \\
\text { groups }^{42,45,46} \\
\text { ( } \uparrow) \text { Belowground } \\
\text { groups }\end{array}$ & $\begin{array}{l}(\uparrow) \text { Aboveground } \\
\text { groups }{ }^{42,47,48} \\
(\uparrow) \text { Belowground } \\
\text { groups }\end{array}$ \\
\hline $\begin{array}{l}\text { Deadwood volume } \\
\left(\mathrm{m}^{3} / \mathrm{ha}\right)\end{array}$ & $\begin{array}{l}\text { Increases resource and } \\
\text { habitat for saproxylic } \\
\text { species } \\
\text { (arth-49-51 } \\
\text { bryophytes on } \\
\text { deadwood, deadwood } \\
\text { fungi) }\end{array}$ & $\begin{array}{l}\uparrow \text { Saproxylic } \\
\text { species }^{23,24,33,44,50-55}\end{array}$ & $\begin{array}{l}(\uparrow) \text { Saproxylic } \\
\text { species }^{23,50,51}\end{array}$ & $\begin{array}{l}(\uparrow) \text { Saproxylic } \\
\text { species }\end{array}$ & \\
\hline Stand heterogeneity & $\begin{array}{l}\text { Increases the number } \\
\text { of available niches }\end{array}$ & & & & \\
\hline Tree diversity & $\begin{array}{l}\text { Alters resource } \\
\text { composition and } \\
\text { increases microhabitat } \\
\text { diversity }{ }^{56,57} \text { Could } \\
\text { affect stand } \\
\text { microclimate }^{58} \text {. }\end{array}$ & $\begin{array}{l}\uparrow \text { All } \\
\text { groups } 25,29,31,59-63\end{array}$ & & $\begin{array}{l}(\uparrow) \text { All } \\
\text { groups }^{29,60,64,65}\end{array}$ & \\
\hline
\end{tabular}




\begin{tabular}{|c|c|c|c|c|}
\hline Vertical heterogeneity & $\begin{array}{l}\text { Increases niche diversity } \\
\text { for groups using the } \\
\text { vertical space, a higher } \\
\text { number of layers could } \\
\text { also increase resource } \\
\text { type for herbivores } \\
\text { Co. } \\
\text { Could decrease ground } \\
\text { light/radiation and } \\
\text { impact animal } \\
\text { movement }^{66,67}\end{array}$ & $\begin{array}{l}(\uparrow \downarrow) \text { Aboveground } \\
\text { groups }^{23,38,68-71}\end{array}$ & & $\begin{array}{l}(\uparrow) \text { Aboveground } \\
\text { groups }\end{array}$ \\
\hline $\begin{array}{l}\text { Horizontal } \\
\text { heterogeneity }\end{array}$ & $\begin{array}{l}\text { Increases niche diversity. } \\
\text { Could affect variation of } \\
\text { stand microclimate }^{72}\end{array}$ & $(\uparrow)$ All groups ${ }^{26,68-71}$ & & $(\uparrow)$ All groups ${ }^{29}$ \\
\hline Deadwood diversity & $\begin{array}{l}\text { Increases resource } \\
\text { diversity for saproxylic } \\
\text { species (arthropods, } \\
\text { lichens and bryophytes } \\
\text { on deadwood, deadwood } \\
\text { fungi) }\end{array}$ & $\begin{array}{l}\uparrow \text { Saproxylic } \\
\text { species }^{23,25,33,44,54,73}\end{array}$ & $\begin{array}{l}\text { ( } \uparrow) \text { Saproxylic } \\
\text { species }^{54}\end{array}$ & $\begin{array}{l}(\uparrow) \text { Saproxylic } \\
\text { species }\end{array}$ \\
\hline
\end{tabular}

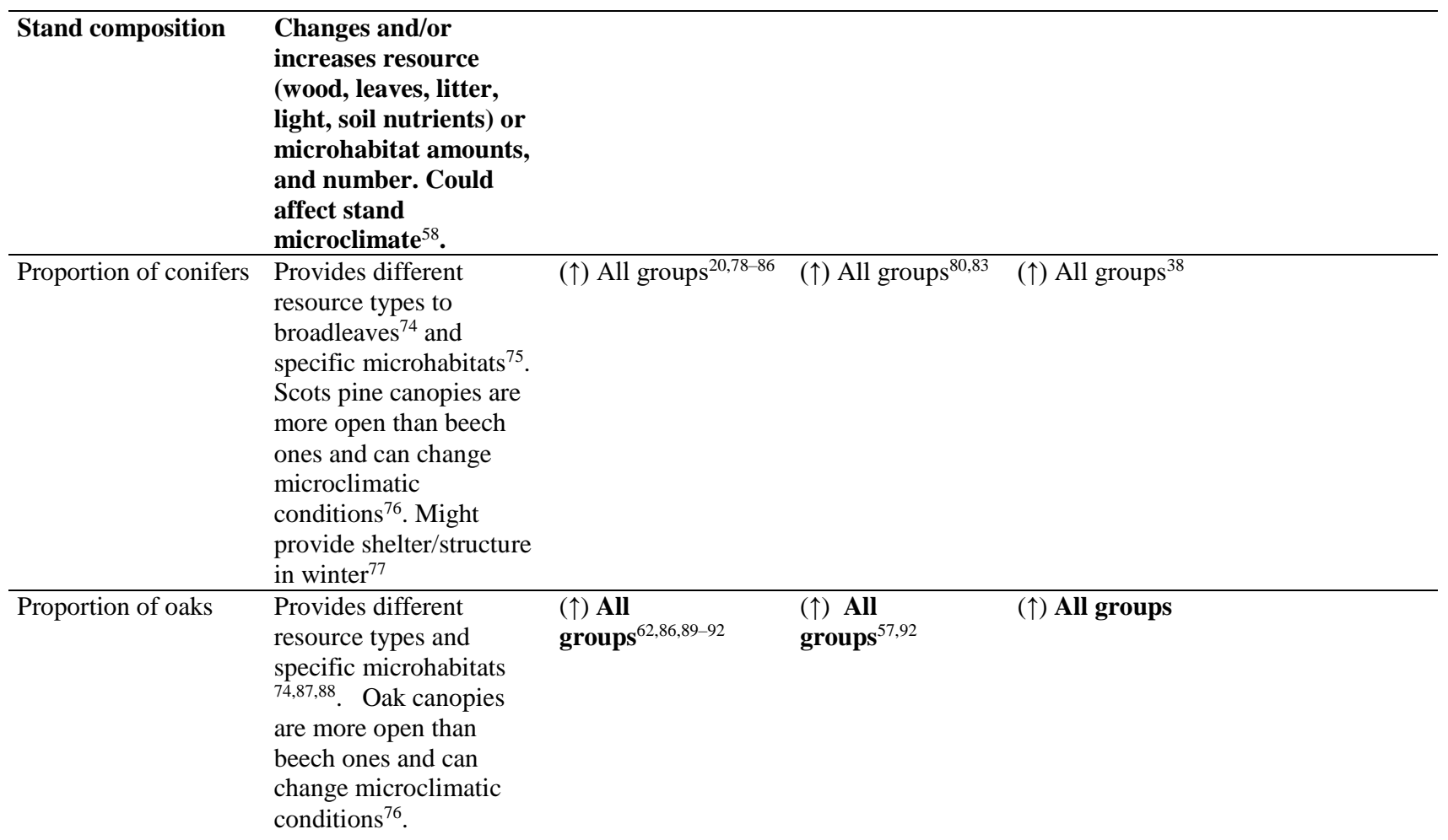


691 Figure 1: Effects of forest features on all 13 trophic groups for each community dimension. Effect 692 sizes are standardised regression coefficients extracted from linear models corrected for region and

693 soil characteristics. Forest-feature effects on abundance, richness and completeness are concordant

694 (most dots in grey quadrants for effect-size plots of pairs of these dimensions), while they are

695 discordant between effects on specialisation and effects on the other dimensions (most dots in white 696 quadrants). Thin error bars highlight p-values greater than 0.05 (non-corrected for False Discovery 697 Rates), while bold ones are added to estimates that are significantly different from 0.
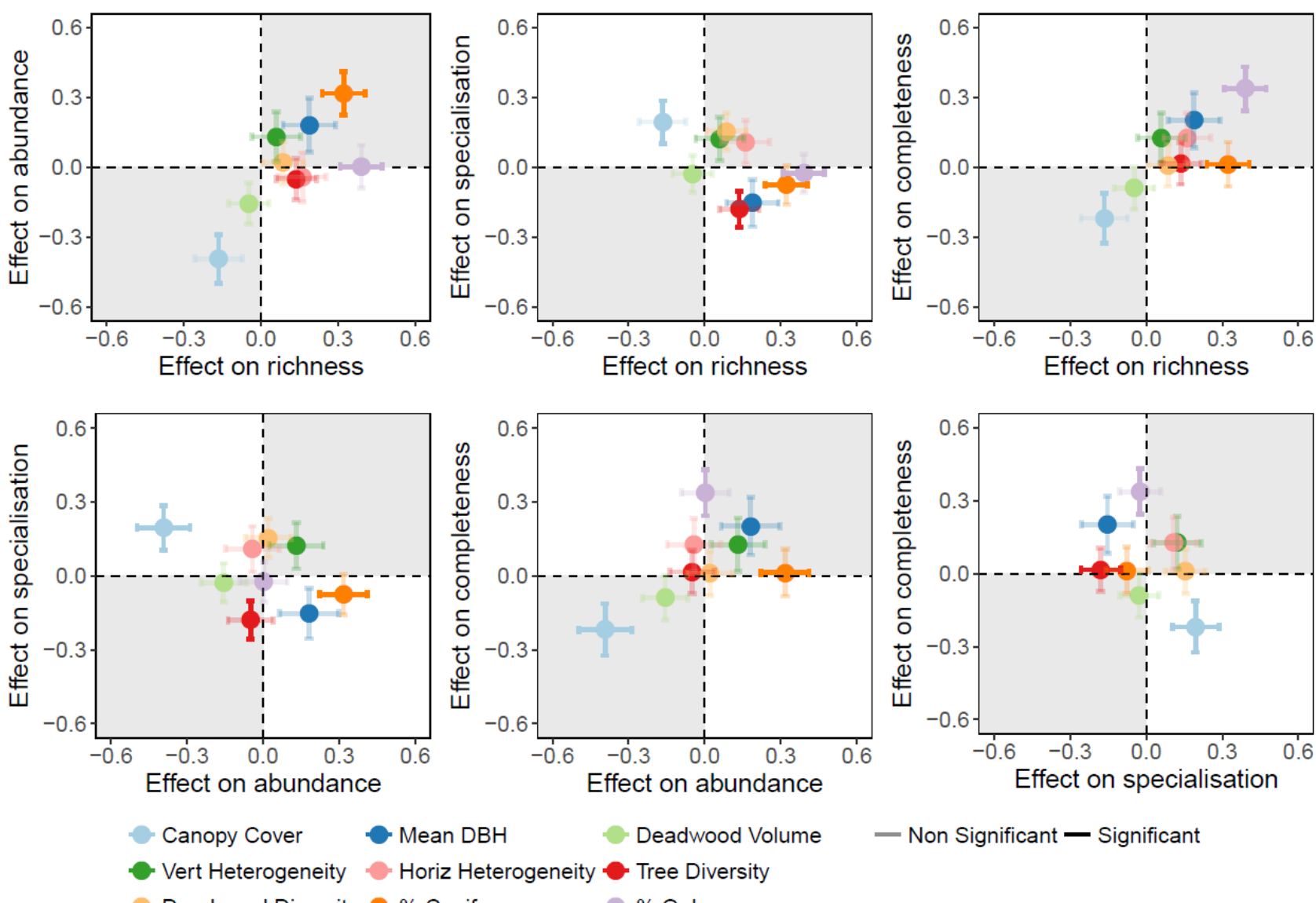

— Non Significant — Significant

- Deadwood Diversity - \% Conifer

$\%$ Oak 
700 Figure 2: Effects (standardised regression coefficient estimates) of forest features on richness,

701 abundance, forest specialisation, and completeness of 13 trophic groups. Blue indicates positive and

702 red indicates negative effects. Significance codes: 0 ' $* * *$ ’ 0.001 ' **' 0.01 ' $*$ ’ 0.05 '.' 0.1 . Symbols

703 in grey indicate non-significant effects after controlling for false discovery rates (20\% threshold).

704 The last column of each panel indicates the average of absolute total effects for each group across all

705 forest features, inverse weighted by their standard errors. "All-groups", "Aboveground" and

706 "Belowground" indicate multidiversity, -abundance, -specialisation and -completeness calculated for

707 different sets of trophic groups (excluding the groups for which we had no information, white rows).

708 We did not have abundance or specialisation for deadwood fungi. Soil fungal abundance includes all

709 three trophic groups together.

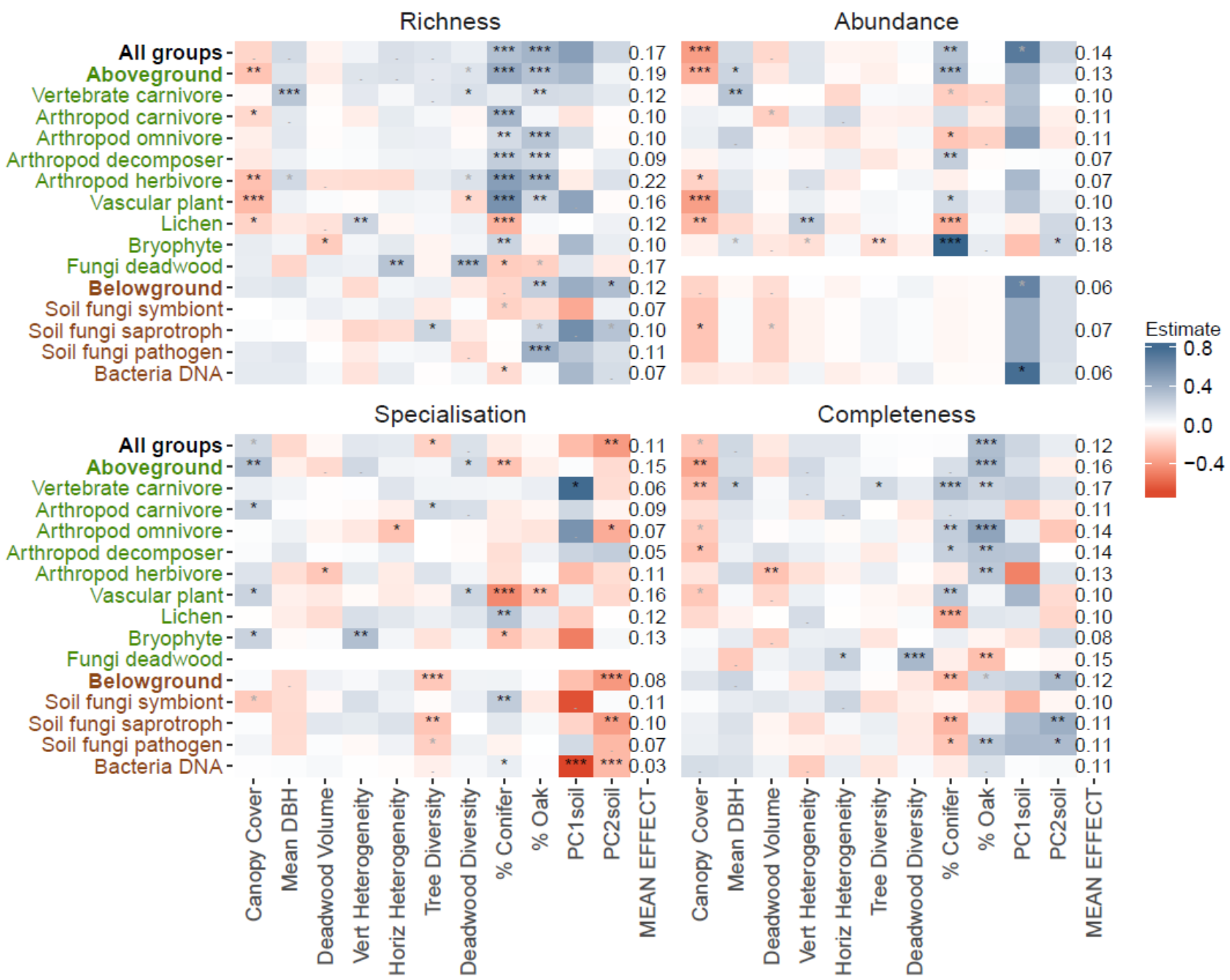

